\title{
Flexibacter maritimus is the agent of 'black patch necrosis' in Dover sole in Scotland
}

\author{
J. F. Bernardet ${ }^{1}$, A. C. Campbell ${ }^{2}$, J. A. Buswell ${ }^{3}$ \\ ${ }^{1}$ Laboratoire d'Ichtyopathologie, Station de Virologie Immunologie Moléculaires, Institut National de la Recherche Agronomique, \\ F-78350 Jouy-en-Josas, France \\ ${ }^{2}$ Science Department, Seale-Hayne College, Newton Abbot, Devon TQ12 6NQ, United Kingdom \\ ${ }^{3}$ Department of Biochemistry, The University of Georgia, Athens, Georgia 30602, USA
}

\begin{abstract}
A Flexibacter columnaris-like bacterium (Strain NCMB 2158), isolated from Dover sole suffering from 'black patch necrosis' (BPN) in Scotland, was compared to $F$. columnaris, F. psychrophilus, F. maritimus, and to all other valid Flexibacter and Cytophaga species. Investigation of phenotypic characteristics showed the unidentified isolate to be more closely related to $F$. maritimus to than $F$. columnaris. DNA was subsequently extracted from each of the studied strains and compared using the DNA/DNA hybridization method. The very high DNA relatednes5 of Strain NCMB 2158 with $2 F$. maritimus reference strains and its insignificant homology with all of the other strains confirmed that the Dover sole isolate belonged to the species $F$. maritimus. These results have resolved the bacterial aetiology of BPN and reveal for the first time the existence of $F$. maritimus elsewhere than in Japan.
\end{abstract}

During the 1970's, commercial production of Dover sole Solea solea juveniles at the Sea Fish Industry Authority, Marine Cultivation Unit, Hunterston, Ayrshire, Scotland, was adversely affected by a persistent disease known as 'black patch necrosis' (BPN). The skin lesions associated with the disease have been described by McVicar \& White (1979): they begin as slight blistering of the skin surface or as dark areas between caudal and marginal fins. This darkening rapidly expands, and the loss of epithelial surface exposes haemorrhagic dermal tissues. The lesions develop into necrotic ulcers due to invasion by saprophytic organisms. In young fish, the condition can progress rapidly, causing mortalities up to $10 \% \mathrm{~d}^{-1}$. The same authors noted a similarity to the lesions found in columnaris disease of freshwater fish and surmised an infectious aetiology. They failed to isolate any bacterial agent, but showed that no virus was involved and that the disease was strongly related to stress and particularly to skin surface conditions: the introduction of sand on tank floors resulted in a dramatic improve- ment, with the disease being virtually eliminated (McVicar \& White 1982).

Subsequently, similar bacterial strains were repeatedly isolated from necrotic lesions of diseased Dover sole and one of them was compared with a reference Flexibacter columnaris strain (NCMB 1038): the isolate and the type culture were identical with respect to cell morphology, oxidase test, production of catalase and $\mathrm{H}_{2} \mathrm{~S}$, gelatin liquefaction, degradation of tyrosine, and hydrolysis of casein, Tween 20, and starch. In addition, the isolates showed similar patterns of sensitivity to a range of antibiotic (Campbell \& Buswell 1982). These results suggested that BPN was provoked by a $F$. columnaris-like bacterium (Campbell \& Buswell 1981). However, the Dover sole isolate was shown to have an absolute requirement for seawater, whereas $F$. columnaris failed to grow on seawatercontaining media. The role of the $F$. columnaris-like bacterium as the aetiological agent of BPN was demonstrated: the organism was repeatedly isolated from diseased tissue but not from healthy tissue; it was highly pathogenic to experimentally infected Dover sole, provoking $100 \%$ mortality within 96 h at $17.5^{\circ} \mathrm{C}$; and it was reisolated from every infected fish (Campbell \& Buswell 1982). A representative isolate was deposited in the National Collection of Industrial and Marine Bacteria (NCIMB, Aberdeen, Scotland) under the code NCMB 2158.

Despite the strong resemblance to the known fish pathogen Flexibacter columnaris, it is unlikely that the fish isolate belongs in this species: several strains of a given bacterial species may differ slightly in their $\mathrm{NaCl}$ tolerance, but there are few examples of bacteria able to grow as well in seawater as in freshwater. This was the opinion of Baxa et al. (1986) who stated that being 
of marine origin, the microorganism could not be considered as $F$. columnaris'. In fact, the bacterial isolate NCMB 2158 seemed closer phenotypically to $F$. maritimus, another fish-pathogenic species, than to $F$. columnaris (L. B. Perry, NCIMB, pers. comm.).

Flexibacter maritimus was isolated in Japan by Hikida et al. (1979) from species of marine fish suffering from a disease first described by Masumura \& Wakabayashi (1977). A detailed study of 15 strains was published by Wakabayashi et al. (1984) who showed that the bacterium had an absolute requirement for seawater. These authors demonstrated the pathogenicity of the bacterium and they proposed a new species, 'F. marinus'. However, it was the opinion of Austin \& Allen-Austin (1985) that a detailed comparison to existing species remains to be done'. Wakabayashi et al. (1986) validated the new species under the name $F$. maritimus and proposed a type strain (NCMB 2154 ${ }^{\mathrm{T}}$ ) but these authors did not investigate the molecular biology of their strains. Baxa et al. (1987) confirmed the

Table 1. Cytophaga and Flexibacter strains included in this study. Abbreviations are: ATCC: American Type Culture Collection, Rockville, USA, NCIB, NCMB: National Collection of Industrial and Marine Bacteria, Aberdeen, Scotland; DSM: Deutsche Sammlung von Mikroorganismen, Göttingen, FRG; JCM: Japanese Collection of Microorganisms, Tokyo, Japan; Holt: R. A. Holt, Departmont of Microbiology, Oregon State University, USA; Wakabayashi: H. Wakabayashi, Department of Fisheries, Faculty of Agriculture, University of Tokyo, Tokyo, Japan; Farkas: J. Farkas, Fisheries Research Institute, Szarvas, Hungary; TG: Laboratoire d'Ichtyopathologie, Insitut National de la Recherche Agronomique, Thiverval-Grignon, France; LNPAA: Laboratoire National de Pathologie des Animaux Aquatiques, IFREMER, Centre de Brest, Plouzané, France

\begin{tabular}{|c|c|c|}
\hline Name as received & Strain & Source \\
\hline C. aquatilis & DSM $2063^{\mathrm{T}}$ & Gills of diseased salmon, Michigan \\
\hline C. arvensicola & $\mathrm{JCM} 2836^{\top}$ & Soil, Osaka, Japan \\
\hline C. fermentans ${ }^{a}$ & NCMB $2218^{\mathrm{T}}$ & Marine mud, California \\
\hline C. flevensis & DSM $1076^{T}$ & Lake Ijsselmeer, The Netherlands \\
\hline C. heparina & NCIB $9290^{\mathrm{T}}$ & Soil \\
\hline C. hutchinsonii & NCIB $9469^{\mathrm{T}}$ & Soil \\
\hline C. johnsonae & DSM $2064^{\mathrm{T}}$ & Soil or mud, Rothamsted or Cambridge, England \\
\hline C. latercula ${ }^{a}$ & NCMB $1399^{\mathrm{T}}$ & Outflow of marine aquarium, California \\
\hline C. lytica & NCMB $1423^{\mathrm{T}}$ & Beach mud, Limon, Costa Rica \\
\hline C. salmonicolor ${ }^{a}$ & $\mathrm{NCMB} 2216^{\mathrm{T}}$ & Marine mud, Califormia \\
\hline 'C allerginae' & ATCC 35408 & Water in industrial air-cooling unit, United States \\
\hline F. aggregans ${ }^{a}$ & NCMB $1443^{\mathrm{T}}$ & Beach sand, Tema, Ghana \\
\hline F. aurantiacus & NCMB $1382^{\mathrm{T}}$ & Garden soil, Minnesota \\
\hline F. canadensis & ATCC $29591^{\mathrm{T}}$ & Soil. Canada \\
\hline F. flexilis & $\mathrm{NCMB} 1377^{\mathrm{T}}$ & Lily pond, San Jose, Costa Rica \\
\hline F. litoralis ${ }^{a}$ & $\mathrm{NCMB} 1366^{\mathrm{T}}$ & Outflow of marine aquarium, California \\
\hline F. polymorphus a & $\operatorname{ATCC} 27820^{\mathrm{T}}$ & Decaying ascidian, La Paz, Mexico \\
\hline F. roseolus & $\mathrm{NCMB} 1433^{\mathrm{T}}$ & Hot spring, Agua Caliente, Costa Rica \\
\hline F. ruber & NCMB $1436^{\mathrm{T}}$ & Hot spring, Geysir, Iceland \\
\hline F. sancti & NCMB $1379^{\top}$ & Buenos Aires, Argentina \\
\hline F. tractuosus ${ }^{\circ}$ & $\mathrm{NCMB} 1408^{\mathrm{T}}$ & Sand, Nhatrang, Vietnam \\
\hline \multirow[t]{3}{*}{ F. maritimus ${ }^{a}$} & NCMB $2154^{\mathrm{T}}$ & Diseased red sea bream (Pagrus major) kidney, Hiroshima, Japan \\
\hline & NCMB 2153 & Diseased black sea bream (Acanthopagrus schlegeli) kidney, Hiroshima, Japan \\
\hline & NCMB 2158 & Dover sole (Solea solea) skin lesions, Scotland \\
\hline \multirow{8}{*}{ F. columnaris } & NCMB 1038 & Salmonid, United States \\
\hline & $\mathrm{NCMB} 2248^{\mathrm{T}}$ & Morphological variant of strain NCMB 1038 \\
\hline & Holt DD3-69 & Adult chinook salmon (Oncorhynchus tshawytscha) gill lesions, Oregon \\
\hline & Holt IC $8-69$ & Young catfish (Ictalurus sp.) kidney, Idaho \\
\hline & Wakabayashi EK28 & Japanese eel (Anguilla japonica) gill lesions, Japan \\
\hline & Farkas $\mathrm{H} 82 / 7$ & Carp (Cyprinus carpio) skin ulcer, Hungary \\
\hline & TG $39 / 87$ & Adult black bullhead (Ictalurus melas) skin ulcer, France \\
\hline & TG 44/87 & Brown trout fry (Salmo trutta) skin lesions, France \\
\hline \multirow[t]{7}{*}{ F. psychrophilus } & $\mathrm{NCMB} 1947^{\mathrm{T}}$ & Coho salmon (Oncorhynchus kisutch) kidney. Washington \\
\hline & Holt SH3-81 & Coho salmon kidney, Oregon \\
\hline & TG 02/86 & Rainbow trout fry (Oncorhynchus mykiss) kidney, France \\
\hline & TG 28/86 & Adult rainbow trout skin lesions, France \\
\hline & LNPAA P01/88 & Rainbow trout fry spleen, France \\
\hline & TG P02/88 & Rainbow trout fry spleen, France \\
\hline & LNPAA P03/88 & Rajnbow trout fry spleen, France \\
\hline
\end{tabular}


Table 2. Phenotypic characteristics differentiating F. maritimus from F. columnaris, F. psychrophilus, and from all other valid Flexibacter and Cytophaga species. Symbols are +: all strains give a positive reaction; $(+)$ : all strains give a weak positive reaction; -: all strains give a negative reaction; $d$ : different reactions; $x / 21$ : no. strains giving a positive reaction per no. strains tested

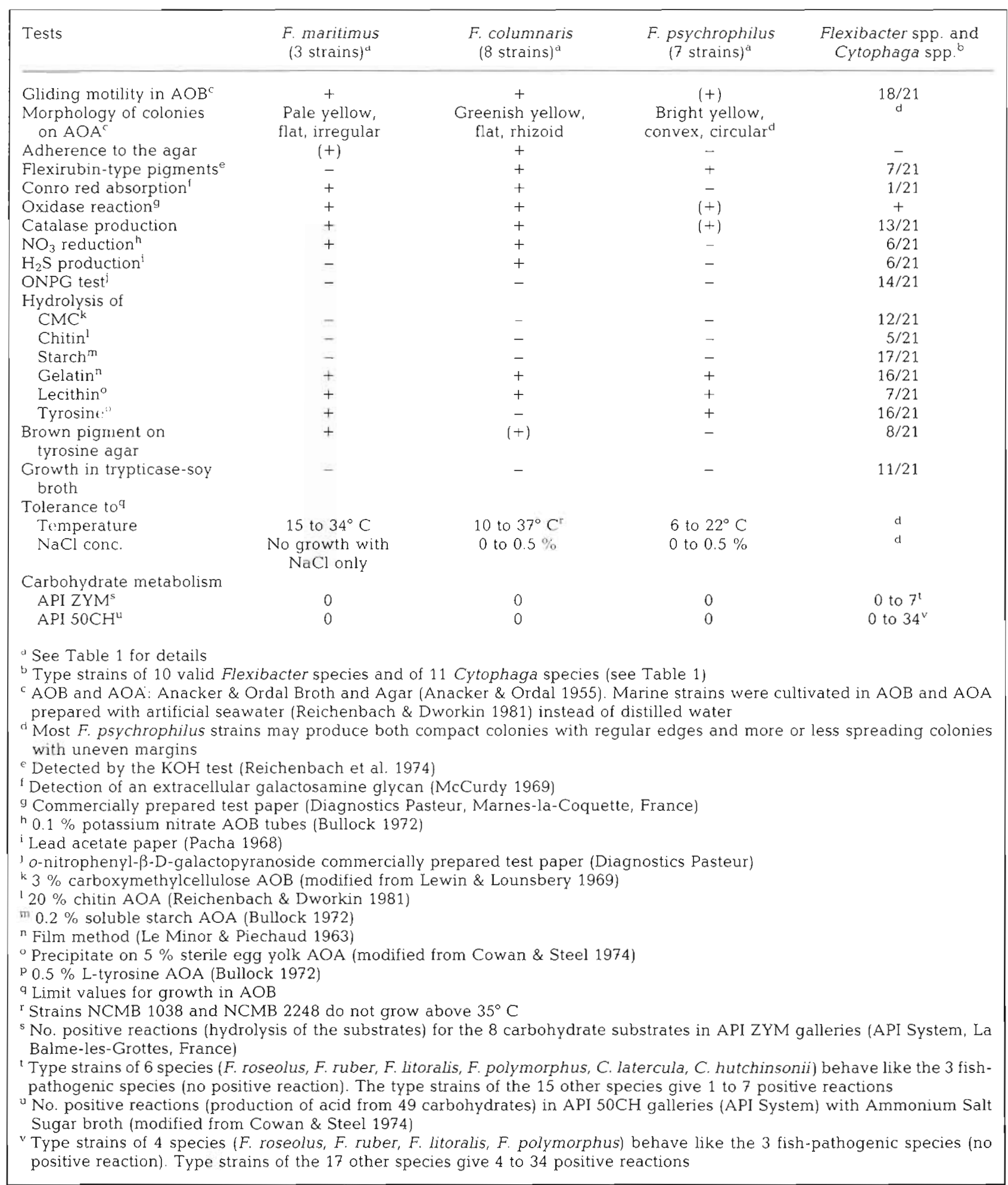


homogeneity of a group of $F$. maritimus strains using numerical and molecular taxonomy methods, but did not cumpare $F$. maritinus to other Flexibacter and Cytophaga species. Indeed, until very recently, $F$. maritimus had been isolated exclusively in Japan, from several marine fish species.

In the course of an extensive study of gliding bacteria isolated from diseased fish in France, a comparison of their morphological, physiological, and biochemical characteristics with those of the type strains of all valid Flexibacter and Cytophaga species led to the first identification of F. columnaris (Bernardet 1989) and of $F$. psychrophilus ('C. psychrophila') (Bernardet \& Kerouault 1989) in France. Molecular studies using the DNA/ DNA hybridization method proved both species to be distinct from all other valid species. The 2 species were described and validated, and type strains designated (Bernardet \& Grimont 1989).

Previously described methods (see Table 2 footnotes) were used to compare Strain NCMB 2158 isolated from Dover sole with the 2 Flexibacter maritimus reference strains deposited in the NCIMB (NCMB 2153 and NCMB $2154^{\mathrm{T}}$ ) and with all other species and strains included in the study (Table 1). Results of the phenotypic investigations (Table 2) showed Strain NCMB 2158 to be identical to $F$. maritimus, while several differences were noted in comparisons with $F$. columnaris. This similarity was unequivocally confirmed by the very high DNA relatedness among the 3 strains: $F$. maritimus $\mathrm{NCMB} 2154^{\mathrm{T}}$ and the unidentified isolate NCMB 2158 were more than $73 \%$ related to $F$. maritimus NCMB 2153 and only 0 to $8 \%$ related to all of the other organisms studied (Bernardet \& Grimont 1989). These 3 strains should thus be considered as belonging to the same bacterial species, according to the definition of this taxon provided by Wayne et al. (1987).

The following conclusions have been drawn from these results: (1) Comparison of the DNA from Flexibacter maritimus with all of the other Flexibacter and Cytophaga species confirms that $F$. maritimus is a genomic species, thus justifying the proposal of a new species by Wakabayashi et al. (1986). (2) The aetiology of 'black patch necrosis' of Dover sole in Scotland is resolved: the bacterial agent is F. maritimus. (3) This is the first identification of F. maritimus elsewhere than in Japan. It is more than likely that this bacterium exists in other locations in Europe, because diseases closely resembling 'black patch necrosis' frequently occur in farmed marine fish in several European countries

\section{LITERATURE CITED}

Anacker, R. L., Ordal, E. J. (1955). Study of a bacteriophage infecting the myxobacterium Chondrococcus columnaris. J Bacteriol. 70: 738-741
Austin, B., Allen-Austin, D. (1985). Bacterial pathogens of fish: a review. J. Appl. Bacteriol. 58: 483-506

Baxa, D. V., Kawai, K., Kusuda, R. (1986). Characteristics of gliding bacterid isulated from diseased cultured flounder Paralichthys olivaceus. Fish Pathol. 21: 251-258

Baxa, D. V., Kawai, K., Kusuda, R. (1987). Molecular taxonomic classification of gliding bacteria isolated from diseased cultured flounder. Fish Pathol. 22: 11-14

Bernardet, J. F. (1989). 'Flexibacter columnaris': first description in France and comparison with bacterial strains from other origins. Dis. aquat. Org. 6: 37-44

Bernardet, J. F., Grimont. P. A. D. (1989). Deoxyribonucleic acid relatedness and phenotypic characterization of Flexibacter columnaris sp. nom., nom. rev., Flexibacter psychrophilus sp. nom., nom. rev., and Flexibacter maritimus Wakabayashi, Hikida, and Masumura 1986. Int. J. syst. Bacteriol 39: 346-354

Bernardet, J. F., Kerouault, B. (1989). Phenotypic and genomic studics of 'Cytophaga psychrophila' isolated from diseased rainbow trout (Oncorhynchus mykiss) in France. Appl. environ. Microbiol. 55: 1796-1800

Bullock, G. L. (1972). Studies on selected Myxobacteria pathogenic for fishes. US Dept int., Fish Wildl. Serv. Bur. Sport Fish. Wildl. Techn. pap. n 60: 4-19

Campbell, A. C., Buswell, J. A. (1981). A Flexibacter columnaris-like bacterium: the aetiological agent of 'black patch necrosis' in farmed Dover sole (Solea solea L.). Society for General Microbiology Quarterly. 8: 275-276

Campbell, A. C., Buswell, J. A. (1982). An investigation into the bacterial aetiology of 'black patch necrosis' in Dover sole (Solea solea L.). J. Fish Dis. 5: 495-508

Cowan, S. T., Steel, K. J. (1974). Manual for the identification of medical bacteria, 2nd edn. Cambridge University Press, Cambridge

Hikida, M., Wakabayashi, H., Egusa, S., Masumura, K. (1979). Flexibacter sp., a gliding bacterium pathogenic to some marine fishes in Japan. Bull. Jpn Soc. Sci. Fish. 45: $421-428$

Le Minor, L., Piechaud, M. (1963). Une méthode rapide de recherche de la protéolyse de la gélatine. Annls Inst Pasteur, Paris 105: 792-794

Lewin, R. A., Lounsbery, D. M. (1969). Isolation, cultivation and characterization of flexibacteria. J. gen. Microbiol. 58 $145-170$

Masumura, K., Wakabayashi, H. (1977). An outbreak of gliding bacterial disease in hatchery-born red sea bream ( $P a g-$ rus major) and gilthead (Acanthopagrus schlegeli) fry in Hiroshima. Fish Pathol. 12: 171-177

McCurdy, H. D. (1969). Studies on the taxonomy of the Myxobacterales. I. Record of Canadian isolates and survey of methods. Can. J. Microbiol. 15: 1453-1461

McVicar, A. H., White, P. G. (1979). Fin and skin necrosis of cultivated Dover sole, Solea solea. J. Fish Dis. 2: 557-562

McVicar, A. H., White, P. G. (1982). The prevention and cure of an infectious disease in cultivated juvenile Dover sole, Solea solea (L.). Aquaculture 26: 213-222

Pacha, R. (1968). Characteristics of Cytophaga psychrophila (Borg) isolated during outbreaks of bacterial cold-water disease. A.ppl Microbiol. 16: 97-101

Reichenbach, H., Kleinig, H., Achenbach, H. (1974). The pigments of Flexibacter elegans: novel and chemosystematically useful compounds. Arch. Microbiol, 101: 131-144.

Reichenbach, H., Dworkin, M. (1981). The order Cytophagales (with addenda on the genera Herpetosyphon, Saprospira, and Flexithrix). In: Starr, M. P, et al. (ed.). The pokaryotes, Vol. 1. Springer-Verlag, New-York, p. 356-379 
Wakabayashi, H., Hikida, M., Masumura, K. (1984). Flexibacter infection in cultured marine fish in Japan. Helgolander Meeresunters. 37: 587-593

Wakabayashi, H., Hikida, M., Masumura, K. (1986). Flexibacter maritimus $\mathrm{sp}$. nov., a pathogen of marine fishes. Int. J. Syst. Bacteriol. 36: 396-398

Responsible Subject Editor Dr T Evelyn, Nanaimo, B.C. Canada
Wayne, L. G., Brenner, D. J., Colwell, R. R., Grimont, P. A. D. Kandler, O., Krichevsky, M. I., Moore, L. H., Moore, W. E. C. Murray, R. G. E., Stackebrandt, E., Starr, M. P., Trüper, H. G. (1987). Report of the Ad Hoc Committee on Reconcliation of Approaches to Bacterial Systematics. Int. J. Syst. Bacteriol. $37 \cdot 463-464$

Manuscript first received: September 29, 1989 Revised version accepted: April 10, 1990 